\title{
OPTIMIZATION OF POLYNOMIAL TRANSITION CURVES FROM THE VIEWPOINT OF JERK VALUE
}

\author{
K. ZBOINSKI ${ }^{1}$, P. WOZNICA ${ }^{2}$
}

\begin{abstract}
The aim of the presented paper is to show the results of shape optimization of railway polynomial transition curves (TCs) of $5^{\text {th }}, 7^{\text {th }}$, and $9^{\text {th }}$ degrees through the use of the full vehicle model and new criteria of assessement concerning the jerk value. The search for the proper shape of TCs means that in this work, the evaluation of TC properties is based on select quantities and the generation of such a shape through the use of mathematically understood optimization methods. The studies presented have got a character of the numerical tests. For this work, advanced vehicle models describing dynamical track-vehicle and vehicle-passenger interactions as well as optimization methods were exploited. In the software vehicle model of a 2-axle freight car, the track discrete model, non-linear descriptions of wheel-rail contact are applied. This part of the software, the vehicle simulation software, is combined with a library optimization procedure into the final computer program.
\end{abstract}

Keywords: railway polynomial transition curves, computer simulation, optimization

\section{INTRODUCTION}

The issue of searching for the proper shape of railway transition curves (TCs) is as old as their use (e.g. [2], [4], [6] - [12]). Nowadays, however, there is a group of scientists and practitioners who claim quite categorically that the problem is sufficiently examined, and further progress in this area it is not possible. They are satisfied by a $3^{\text {rd }}$ degree parabolic TC and its corresponding linear superelevation ramp. Many works (e.g. [12]) and works of the authors of this paper ([2], [6], [9]) on the problems of the dynamics of railway vehicles in transition curves show that this issue is not trivial, and the expectation of an immediate breakthrough solution would be rather artless. Probably it has just discouraged many researchers (aimed at quick success), who do not understand

\footnotetext{
${ }^{1}$ Warsaw University of Technology, Faculty of Transport 00-662, 75 Koszykowa Street, kzb@wt.pw.edu.pl

${ }^{2}$ Warsaw University of Technology, Faculty of Transport 00-662, 75 Koszykowa Street, pwoznica@wt.pw.edu.pl
} 
or do not accept that in many areas of research progress is slow. From the authors' point of view, the cause of some reluctance against a change of methods in formation of TCs in engineering practice is primarily the traditional views treated incorrectly as invariants. Those views which the authors of the article polemize with the most are presented in the current chapter.

1. Let's start with polemics from the belief that the construction of TCs other than with a linear change of curvature creates geodetic difficulties impossible to overcome. In the authors' opinion, if the TC is represented by a set of coordinates it does not matter which TC is just laid out; neither machines nor people performing this task need to know it. The accuracy of construction of any TC is the same. Moreover, it was shown many years ago in [4], that differences in coordinates of various TCs are much larger (both in the plan and the elevation) than errors in TCs' alignment. In this context, the opinion that problems with the alignment of polynomial TCs of high degree cannot be overcome, has no real justification at this time.

2. Another issue worth mentioning is how to compare and evaluate TCs of different shapes. The fundamental error committed here is to compare the curves of the same length equal to length for the $3^{\text {rd }}$ degree parabola. In such conditions, curves with a linear change of curvature and superelevation ramp always are the best, because of the constant superelevation ramp inclination value. To take advantage of TCs of other shapes - polynomials of $5^{\text {th }}, 7^{\text {th }}, 9^{\text {th }}$, and $11^{\text {th }}$ degrees, one should assume their lengths in a such way that the maximum values of the superelevation ramp inclination have reasonable values. Standard TCs of mentioned degrees have the feature such that the integral of the centrifugal force acting on the vehicle body along the route is minimal. If we take the length of the $3^{\text {rd }}$ degree parabola as 1 and the same value of the maximum inclination of the superelevation ramp for mentioned curves, these curves will have a greater length respectively by $1.5,1.875,2.1875$, and 2.46 times. The disadvantage of a significant increase of the length of the curve can be corrected in practice. The regulations [3] allow the use of the double value of maximum inclination of the superelevation ramp for curves with non-linear curvatures in comparison to curves with linear curvatures. In such cases, the maximum inclination of the superelevation ramp has only temporary, and not continuous, character.

3. The other problem is an oversimplified representation of the vehicles in the methods exploited in evaluation and selection of the TCs parameters in engineering practice, and sometimes in research. It seems that an approach where all vehicles are represented by a material point has already exhausted its capability. The simplicity of the model and covering the whole rolling stock, the biggest advantages of the traditional approach, are no longer considered to be a source of progress. In this context, one should notice the trend of separating freight and passenger traffic and 
conducting them with separated routes. In the case of passenger traffic, it is difficult not to notice that traffic is handled often by one type of vehicle, or at most by just several types of very similar properties. The alternative, which for years has been promoted by one of the authors (e.g. [7]), is the individualization of vehicles and their representation by the full nonlinear dynamic model. This gives potential ability to better match the properties of TCs to the group of similar vehicles (freight traffic) or to individual vehicles (passenger traffic of high-speed trains).

4. In engineering practice, the approach to track-vehicle interactions is limited to discussing the vehicles jointly and studying the selected effects (quantities) in the car body [1]. Here, the traditional criteria of 3-dimensional TC formation are in use. They demand that the physical quantities that characterise effects on passengers and, alternatively, on cargo, do not exceed values that are acknowledged as acceptable. The corresponding relations refer to: unbalanced lateral acceleration $a \leq a_{l i m}$, velocity of the $a$ change $\psi \leq \psi_{\text {lim }}$, and velocity of wheel vertical rise along the superelevation $\operatorname{ramp} f \leq f_{\text {lim }}$. Some up-to-date works extend these criteria with additional quantities and search for their courses. Such is, for example, the second time derivative of $a$. In the case of the courses (of the $a$ first and second derivatives most often), the continuity (no abrupt change in values), differentiability (no bends), and so on are demanded. Despite that extension, such criteria do not take account of the dynamical properties of a particular vehicle, including track-vehicle interactions in particular conditions, or effects on vehicle bogies. These mentioned phenomena are quite different than those appearing for traditional criteria, where the track has infinite stiffness and no geometrical irregularities, whereas the vehicle is represented by a single rigid body or particle.

\section{MOTIVATION AND AIMS OF THE CURRENT WORK}

\subsection{MOTIVATION TO UNDERTAKE THE RESEARCH}

The search for the proper shape of railway TCs means to the authors an evaluation of curve properties based on select dynamical quantities and generation of such shapes with the use of mathematically understood optimization methods. The studies presented now and in the past are, in fact, always based on numerical tests. For the needs of the present work, the advanced vehicle model, dynamical track-vehicle and vehicle-passenger interactions as well as optimization methods were exploited. In the model and its corresponding software a complete rail vehicle model of a 2axle freight car, the flexible track discrete models, and non-linear descriptions of wheel-rail contact 
(both geometry and forces) are applied. The part of the software that makes vehicle simulations is combined with library optimization procedures into the final computer program.

The authors of this article, in their earlier works, have shown good dynamic properties of railway polynomial transition curves of higher degrees - 9 and 11 - with the maximum number of terms - 7 and 9, respectively [2], [6], [8], [10]. For optimization criteria they used an integral of the 2-axle railway vehicle body lateral acceleration along the route. The curvatures of the obtained optimum transition curves did not have tangence ( $G_{l}$ continuity) in the terminal points - first and last - of the curve, however. That property was obtained for 2 velocities of vehicles: the bigger one represented unbalanced lateral acceleration in a circular arc equal to $0.6 \mathrm{~m} / \mathrm{s}^{2}$ and the smaller one guaranteed ideal balance between transversal components of gravity and centrifugal force acting on vehicle body; a value of curve radius $(R=600 \mathrm{~m})$ and a value of cant $(H=150 \mathrm{~mm})$ were considered. The property being discussed induced the authors of this paper to clarify why curvature bends $\left(G_{0}\right.$ continuity) in terminal points of obtained TCs have a relatively small negative impact on vehicle dynamics while running along such curves.

\subsection{AIMS OF THE WORK}

In the context of the motivation given above, the aim of this work is the optimization of railway polynomial TCs of $5^{\text {th }}, 7^{\text {th }}$, and $9^{\text {th }}$ degrees through the use of new, non-traditional optimization criteria. As before, the full vehicle model has been used in the optimization process. Finally, the authors wanted to check whether the new optimization criteria and also values of curve radius $R=1200 \mathrm{~m}$ and $2000 \mathrm{~m}$ - and cant $-H=75 \mathrm{~mm}$ and $45 \mathrm{~mm}$ - taken to the analysis could give, in result, so-called smooth TCs.

Mentioned non-traditional assessment criteria concerned the minimization of:

- the value of integral of the change of lateral acceleration (jerk) of the vehicle body along the route:

$$
Q F_{l}=\int_{0}^{L_{C}}\left|\dddot{y}_{b}\right| d l / L_{C},
$$

- the maximum value of the change of lateral acceleration of the vehicle body:

$$
Q F_{2}=\max \left|\ddot{y}_{b}\right|,
$$


where:

$\dddot{y}_{b}$ - the change of lateral acceleration (jerk) of the vehicle body and $L_{C}-$ length of whole TC and the adjacent $100 \mathrm{~m}$ of circular arc.

\section{FUNDAMENTAL PRINCIPLES ADOPTED IN MODELLING}

\subsection{VEHICLE AND TRACK MODELS}

The model represents a 2-axle freight car of average value of parameters. Relatively simple construction of vehicles gives acceptable computation times, which is preferred in basic research and facilitates the interpretation of results. Its structure is shown in Fig. 1c. It is supplemented with discrete models of vertically and laterally flexible track shown in Fig. 1a and 1b. Linearity of the vehicle suspension (stiffness and damping elements) was assumed. The same concerns the track models. One can find all parameters of the vehicle-track system analysed in Table 1.

Note that the model used includes all key elements of vehicle dynamical models recognized in railway vehicle dynamics as: key mass components (wheelsets and vehicle body), suspension components (stifness and damping elements), and wheel and rail geometry described through real non-linear shape of their profiles. Tangential contact forces are calculated through the use of the non-linear simplified contact theory by J.J. Kalker. All inertia terms resulting from motion in a curved track are taken into account with no simplication. In addition, the vehicle model is supplemented with the track model, which means that in fact the dynamical vehicle-track system is considered. It can be treated as the full dynamical model, especially when it is compared to the particle representing the vehicle in engineering traditional methods of TCs formation.

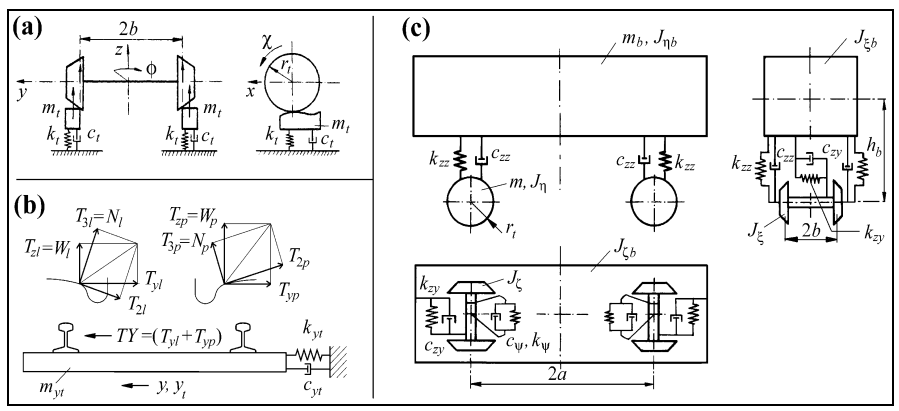

Fig. 1. System's nominal model: a) track vertically, b) track laterally, c) vehicle 
Table 1. Parameters of the analysed vehicle-track system

\begin{tabular}{|c|l|c|c|}
\hline Notation & \multicolumn{1}{|c|}{ Description } & Unit & Param. value \\
\hline$m_{b}$ & vehicle body mass & $\mathrm{kg}$ & 30000 \\
\hline$m$ & wheelset mass & $\mathrm{kg}$ & 2400 \\
\hline$I_{\xi b}$ & vehicle body moment of inertia; longitudinal axis & $\mathrm{kg} \cdot \mathrm{m}^{2}$ & 17500 \\
\hline$I_{\eta b}$ & vehicle body moment of inertia; lateral axis & $\mathrm{kg} \cdot \mathrm{m}^{2}$ & 185000 \\
\hline$I_{\zeta b}$ & vehicle body moment of inertia; vertical axis & $\mathrm{kg} \cdot \mathrm{m}^{2}$ & 185000 \\
\hline$I_{\xi}$ & wheelset moment of inertia; longitudinal axis & $\mathrm{kg} \cdot \mathrm{m}^{2}$ & 1700 \\
\hline$I_{\eta}$ & wheelset moment of inertia; lateral axis & $\mathrm{kg} \cdot \mathrm{m}^{2}$ & 200 \\
\hline$I_{\xi}$ & wheelset moment of inertia; vertical axis & $\mathrm{kg} \cdot \mathrm{m}^{2}$ & 1700 \\
\hline$k_{z z}$ & longitudinal stiffness of the 1st level of suspension & $\mathrm{kN} / \mathrm{m}$ & 1000 \\
\hline$k_{z y}$ & lateral stiffness of the 1st level of suspension & $\mathrm{kN} / \mathrm{m}$ & 800 \\
\hline$k_{z x}$ & vertical stiffness of the 1st level of suspension & $\mathrm{kN} / \mathrm{m}$ & 800 \\
\hline$c_{z z}$ & longitudinal damping of the 1st level of suspension & $\mathrm{kNs} / \mathrm{m}$ & 60 \\
\hline$c_{z y}$ & lateral damping of the 1st level of suspension & $\mathrm{kNs} / \mathrm{m}$ & 47 \\
\hline$c_{z x}$ & vertical damping of the 1st level of suspension & $\mathrm{kNs} / \mathrm{m}$ & 42 \\
\hline$a$ & semi-wheel base & $\mathrm{m}$ & 3.16 \\
\hline$h_{b}$ & vertical distance between mass centres of wheelset and vehicle body & $\mathrm{m}$ & 1.04 \\
\hline$r_{t}$ & wheelset rolling radius & $\mathrm{m}$ & 0.46 \\
\hline$m_{t}$ & vertical mass of the rail & $\mathrm{kg}$ & 200 \\
\hline$k_{t}$ & vertical stiffness of the rail & $\mathrm{kN} / \mathrm{m}$ & 70000 \\
\hline$c_{t}$ & vertical damping of the rail & $\mathrm{kNs} / \mathrm{m}$ & 200 \\
\hline$m_{t y}$ & lateral mass of the track & $\mathrm{kg}$ & 500 \\
\hline$k_{t y}$ & lateral stiffness of the track & $\mathrm{kNs} / \mathrm{m}$ & 25000 \\
\hline$c_{t y}$ & lateral damping of the track & 500 \\
\hline & & & $\mathrm{m}$ \\
\hline
\end{tabular}

\subsection{TYPE OF TRANSITION CURVES ADOPTED IN THE RESEARCH}

As TCs in the studies, the authors of the current work adopted polynomial curves of $5^{\text {th }}, 7^{\text {th }}$, and $9^{\text {th }}$ degrees $(n=5,7$ and 9):

$$
y=\frac{1}{R}\left(\frac{A_{n} l^{n}}{l_{0}^{n-2}}+\frac{A_{n-1} l^{n-1}}{l_{0}^{n-3}}+\frac{A_{n-2} l^{n-2}}{l_{0}^{n-4}}+\frac{A_{n-3} l^{n-3}}{l_{0}^{n-5}}+\ldots . .+\frac{A_{4} l^{4}}{l_{0}^{2}}+\frac{A_{3} l^{3}}{l_{0}^{1}}\right),
$$

$$
k=\frac{d^{2} y}{d l^{2}}=\frac{1}{R}\left[n(n-1) \frac{A_{n} l^{n-2}}{l_{0}^{n-2}}+(n-1)(n-2) \frac{A_{n-1} l^{n-3}}{l_{0}^{n-3}}+\ldots . .+3 \cdot 2 \frac{A_{3} l^{1}}{l_{0}^{l}}\right],
$$

$$
h=H\left[n(n-1) \frac{A_{n} l^{n-2}}{l_{0}^{n-2}}+(n-1)(n-2) \frac{A_{n-1} l^{n-3}}{l_{0}^{n-3}}+\ldots . .+4 \cdot 3 \frac{A_{4} l^{2}}{l_{0}^{2}}+3 \cdot 2 \frac{A_{3} l^{I}}{l_{0}^{1}}\right],
$$




$$
i=\frac{d h}{d l}=H\left[n(n-1)(n-2) \frac{A_{n} l^{n-3}}{l_{0}^{n-2}}+(n-1)(n-2)(n-3) \frac{A_{n-l} l^{n-4}}{l_{0}^{n-3}}+\ldots . .+3 \cdot 2 \cdot 1 \frac{A_{3} l^{0}}{l_{0}^{l}}\right]
$$

where:

$y, k, h$, and $i$ define the curve lateral coordinate, curvature, superelevation, and inclination of superelevation ramp, respectively. The $R, H, l_{0}$, and $l$ define curve minimum radius (at its end), maximum superelevation (at the curve end), total curve length, and curve current length, respectively.

The $A_{i}$ are polynomial coefficients $(i=n, \ldots ., 3)$. Such definition of TCs gives us possibility of proper $k$ and $h$ values at TCs' terminal points. They should be equal to 0 at the initial point and to $1 / R$ and $H$ at the end point. Note that values for both always equal 0 for $l=0$. In order to ensure $1 / R$ and $H$ values for length $l=l_{0}$, normalisation of the coefficients is necessary [6]. Finally, normalized coefficients $A_{i}^{\prime}$ satisfy constraints imposed on their values (condition IDZ=1 [6]). In order to ensure tangence of the $k$ and $h$ functions at their terminal points to the $k$ and $h$ functions for straight track and circular arc (condition IDZ=2 [6]), values of $i$ function given in Eq. (3.4) should be equal to 0 for lengths $l=0$ and $l=l_{0}$. Equation (3.4) always produces 0 for length $l=0$, when its last term is removed. Therefore, this is the first condition that affects the rest of the equations. To ensure 0 value for length $l=l_{0}$, the square bracket in Eq. (3.4) with the last term omitted should equal to 0 . Curvatures for both the parabolic and polynomial TCs are calculated approximately i.e. as the second derivative of the $y$ co-ordinate (3.2). It results in a linear curvature and superelevation ramp for the parabolic curve.

The problem formulated in this article is a classical formulation of static constrained optimization. It is solved with a library procedure that utilizes a moving penalty function algorithm combined with Powell's method of conjugate directions. The objective function must be a real-value function of a fixed number of real-value inputs and it need not be differentiable.

The difficulty of the problem's solution consists in quite a complex form and way to determine the quality function. This function is calculated as a result of the numerical simulation of motion of the mechanical system represented by its model in [6]. The main steps during calculation of the quality function are: generation of the new shape of the transition curve, calculation of the kinematical quantities (velocities and accelerations) that depend on this new shape, and solution of the corresponding $2^{\text {nd }}$ order ordinary differential equations (ODEs) set. 


\section{THE SOFTWARE AND OPTIMIZATION CONDITIONS CHARACTERISTICS}

\subsection{BASIC INFORMATION ABOUT THE SOFTWARE}

The scheme of the software used in TC shape optimization corresponds to that shown e.g. in [9]. The major objects within this scheme are the two iteration loops presented. The first is the integration loop. This loop is stopped when distance $L_{C}$, being the length of the route (usually compound route $\mathrm{ST}, \mathrm{TC}$, and $\mathrm{CC}$ or $\mathrm{CC}, \mathrm{TC}$, and $\mathrm{ST}$ ), is reached by the model. The second is the optimization process loop. It is stopped when the number of iterations reaches limit value $i_{\text {lim }}$. This value means that $i_{\text {lim }}$ simulations of vehicle motion have to be performed in order to stop the optimization process. In the calculations done so far $i_{l i m}=100$ was used as standard value. If the optimum solution is reached earlier, i.e. for $i<i_{l i m}$, then the optimization process stops automatically and the corresponding results are recorded. When no optimum solution is reached for $i_{\text {lim }}=100$, this value has to be increased manually, while the process has to be repeated.

\subsection{INFORMATION ABOUT INITIAL POLYNOMIAL TRANSITION CURVES AND OPTIMIZATION CONDITIONS}

In railway technology a certain group of polynomial TCs is used as a standard most often. Each polynomial of even degree has two different standard transition curves. This property differentiates such polynomials from polynomials of odd degrees (where just one such standard TC exists). In this case, the functions of the inclination of the superelevation ramp - formula (3.4) - of these curves are symmetrical about a vertical axis passing through point $l_{0} / 2$. The method of receiving standard TCs for both even and odd degrees is presented in [12].

In the optimization process three standard TCs [12] were used as initial ones. In [12] also the algorithm of obtaining of each of these curves is presented. The first TC (4.1) is the curve of $5^{\text {th }}$ degree and is known as the Bloss curve in railway engineering, and the remaining TCs (4.2) and (4.3) are of $7^{\text {th }}$ and $9^{\text {th }}$ degrees, respectively. Despite the fact that Bloss TC is used in terraindifficult conditions, the authors decided to take this curve as the TC of $5^{\text {th }}$ degree satisfying the condition described in point no. 2 of chapter 1.

$$
y_{l}=\frac{1}{R}\left(-\frac{l^{5}}{10 l_{0}^{3}}+\frac{l^{4}}{4 l_{0}^{2}}\right),
$$




$$
\begin{gathered}
y_{2}=\frac{1}{R}\left(\frac{l^{7}}{7 l_{o}^{5}}-\frac{l^{6}}{2 l_{o}^{4}}+\frac{l^{5}}{2 l_{0}^{3}}\right), \\
y_{3}=\frac{1}{R}\left(-\frac{5}{18} \frac{l^{9}}{l_{0}^{7}}+\frac{5}{4} \frac{l^{8}}{l_{0}^{6}}-2 \frac{l^{7}}{l_{0}^{5}}+\frac{7}{6} \frac{l^{6}}{l_{0}^{4}}\right) .
\end{gathered}
$$

For each polynomial TC geometrical demands can be imposed; demands one may or may not want to take into account. Possible combinations of coefficients for these demands are presented e.g. in [2]. In this paper the authors focused only on TCs with a maximum number of terms $(n-2)$. This case affects only TCs which have curvatures without tangence in terminal points of a curve (condition IDZ=1).

Each transition curve has a minimum length of $l_{0}$, which is calculated in accordance with the method presented in [5]. This minimum length arises from two conditions, on demand that two values are not to be exceeded. The first one is the velocity of the unbalanced lateral acceleration change $\psi$, and the second is the velocity of wheel vertical rise along the superelevation $\operatorname{ramp} f$. For the purpose of this work, the authors always took a greater length calculated from both conditions $\left(l_{f}\right.$ and $l_{\psi}$ ) and used two formulas well-known from engineering practice [5]:

$$
\begin{aligned}
& l_{f}=\frac{m \cdot H \cdot v}{f}, \\
& l_{\psi}=\frac{m \cdot a_{\text {lim }} \cdot v}{\psi},
\end{aligned}
$$

where: $m$ is a multiplier constant given for all degrees in [12].

While determining the lengths with formulas (4.4) and (4.5), the velocity of wheel vertical rise along the superelevation ramp $f$ was always equal to $56 \mathrm{~mm} / \mathrm{s}$ and the velocity of the unbalanced lateral acceleration change $\psi$ was always equal to $1 \mathrm{~m} / \mathrm{s}^{3}$. Radii of circular arc $R$ were assumed to be equal to $1200 \mathrm{~m}$ and $2000 \mathrm{~m}$ and superelevations $H$ were assumed to be equal to $75 \mathrm{~mm}$ and $45 \mathrm{~mm}$. For given values of $R$ and $H$, the authors always calculated two velocities per vehicle: the lower and the higher, according to well-known engineering practice formula [1] for the speed limit. Lower velocities always corresponded to lateral acceleration in the plane of track $a_{\text {lim }}$ equal to $0 \mathrm{~m} / \mathrm{s}^{2}$, whereas higher velocities corresponded to lateral acceleration equal to $0.3 \mathrm{~m} / \mathrm{s}^{2}$ or $0.6 \mathrm{~m} / \mathrm{s}^{2}$. A complete list of conditions taken into analysis is presented in Tab. 2. 
It is obvious that in this work the authors could not assume the same set of values of velocities (the smaller and bigger one), superelevation, and lateral acceleration for both values of radius of the circular arc. Assuming the conditions taken into analysis, the authors took the values of superelevation as not larger than $150 \mathrm{~mm}$ and velocity as not higher than $140 \mathrm{~km} / \mathrm{h}$. The bigger values of velocity resulted in rail model derailment. The authors are aware that the conditions assumed create a situation that is far from standard engineering practice. Concerning configuration of the test routes: they were always composed of straight track (ST), transition curve (TC), and circular arc (CC). Lengths of ST sections were the same and equal to $50 \mathrm{~m}$. Similarly for CC, their lengths were the same and equal $100 \mathrm{~m}$, so differences between the routes existed for TC sections.

Table 2. Conditions taken to the analysis - different Routes

\begin{tabular}{|c|c|c|c|c|c|}
\hline $\begin{array}{c}\text { Radius of } \\
\text { circular arc } \\
R[\mathrm{~m}]\end{array}$ & $\begin{array}{c}\text { Superelevation } \\
H[\mathrm{~mm}]\end{array}$ & $\begin{array}{c}\text { Lateral } \\
\text { acceleration } \\
a_{\text {lim }}\left[\mathrm{m} / \mathrm{s}^{2}\right]\end{array}$ & $\begin{array}{c}\text { Vehicle velocity } \\
v[\mathrm{~km} / \mathrm{h}]- \\
5^{\text {th }} \text { degree }\end{array}$ & $\begin{array}{c}\text { Vehicle velocity } \\
v[\mathrm{~km} / \mathrm{h}]- \\
7^{\text {th }} \text { degree }\end{array}$ & $\begin{array}{c}\text { Vehicle velocity } \\
v[\mathrm{~km} / \mathrm{h}]- \\
9^{\text {th }} \text { degree }\end{array}$ \\
\hline 1200 & 75 & 0.0 & 87.33 (Route 1) & 87.33 (Route 5) & 87.33 (Route 9) \\
\hline 2000 & 45 & $\begin{array}{l}0.6 \\
0.0 \\
0.3\end{array}$ & $\begin{array}{c}130.21 \text { ( Route } 2) \\
87.33(\text { Route } 3) \\
130.21 \text { (Route } 4)\end{array}$ & $\begin{array}{c}130.21(\text { Route } 6) \\
87.33(\text { Route } 7) \\
130.21 \text { (Route } 8)\end{array}$ & $\begin{array}{c}130.21(\text { Route 10) } \\
87.33(\text { Route } 11) \\
130.21 \text { (Route } 12)\end{array}$ \\
\hline
\end{tabular}

\section{RESULTS OF THE OPTIMIZATION OF RAILWAY TRANSITION CURVES}

\subsection{SELECTED RESULTS. FoCUS ON ROUTE 1}

In this subchapter the authors present selected results of optimization of a railway $\mathrm{TC}$ of $5^{\text {th }}$ degree for Route 1 (Tab. 2) as representative for all the Routes. In general, the results of optimization always consisted of:

- formula for optimum TC,

- formula for curvature corresponding to optimum TC,

- values of optimum polynomial coefficients,

- value of $Q F$ adopted corresponding to optimum polynomial coefficients,

- graphical representation of creepages in wheel-rail contact,

- graphical representation of the lateral displacements $y_{b}$ and accelerations $y^{\prime \prime}{ }_{b}$ of vehicle body and wheelsets,

- graphical representation of search for optimum TC represented by curvatures (superelevation ramps). 
Generally each of the Routes can be represented by its own group of six figures; content of the figures in particular groups is analogous. The first figure in the group represents curvatures $k$ of the initial and optimised TCs. Note that courses of the curvatures $k$ from being the scale of the vertical axis. The second figure in the group represents superelevation ramp slopes of the initial and optimum TCs. The third one represents vehicle body lateral displacements for both the initial and optimised TCs. The fourth figure represents vehicle body lateral accelerations for the initial and optimised TCs. The fifth figure represents the vehicle body's velocity of change of lateral accelerations (jerk) for the initial and optimised TCs. The sixth figure represents front wheelset lateral acceleration for the initial and optimised TCs. Some figures can be supplemented by passages for $3^{\text {rd }}$ degree parabola. The solid line represents results after optimization, while the broken line is at the beginning of the optimization process (and for the $3^{\text {rd }}$ degree parabola).

Parameters of the Route 1 selected from all the routes tested were as follows:

- $5^{\text {th }}$ degree,

- $v=87.33 \mathrm{~m} / \mathrm{s}$,

- $l_{0}=48.73 \mathrm{~m}$,

- $\mathrm{INI}=y_{1}$,

- $Q F_{1}$.

Betterment in the system dynamical properties for the optimised TC shapes in comparison to the initial curve (4.1) is confirmed by simulation results, primarily by the velocity of change of lateral accelerations $y^{\prime \prime \prime} b$ of vehicle body, but also by the displacements $y_{b}$ and accelerations $y^{\prime \prime} b$. The discussed betterment is obvious for the displacements from Fig. 3a and accelerations from Fig. $3 \mathrm{~b}$. The betterment is also, most expressed when values of quality functions are compared. If one assumes the value for the initial curve as equal to $100 \%$, then $Q F$ s value in $\%$ for the optimum TC is $18 \%$.

Additionally, the properties inferior to the optimised $5^{\text {th }}$ degree TCs as compared to the $3^{\text {rd }}$ degree parabolic TC are shown in Fig. 3. It is obvious from the whole Fig. 3 - both for lateral displacements and lateral accelerations of vehicle body.

The optimum curve given by the software is represented by the following formula:

$$
y=\frac{1}{1200}\left(-0.0138591 \cdot \frac{l^{5}}{48.73^{3}}+0.0698105 \cdot \frac{l^{4}}{48.73^{2}}+0.0732425 \cdot \frac{l^{3}}{48.73^{l}}\right) .
$$



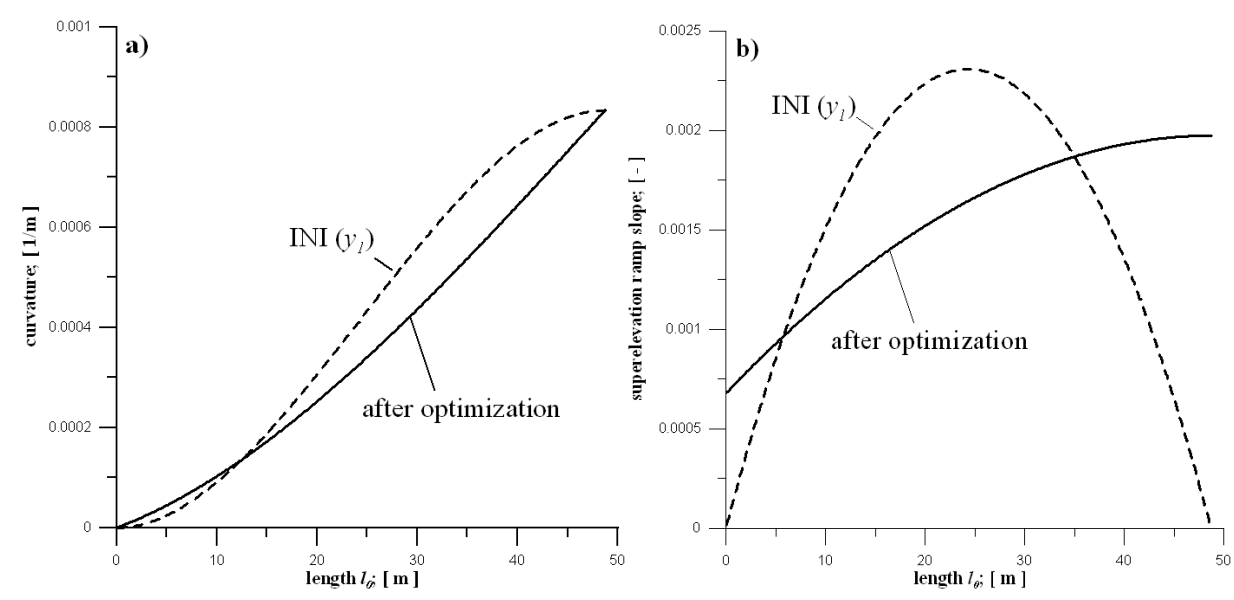

Fig. 2. Route 1: features of TCs: a) curvatures, b) superelevation ramp slope of the initial and optimum TCs
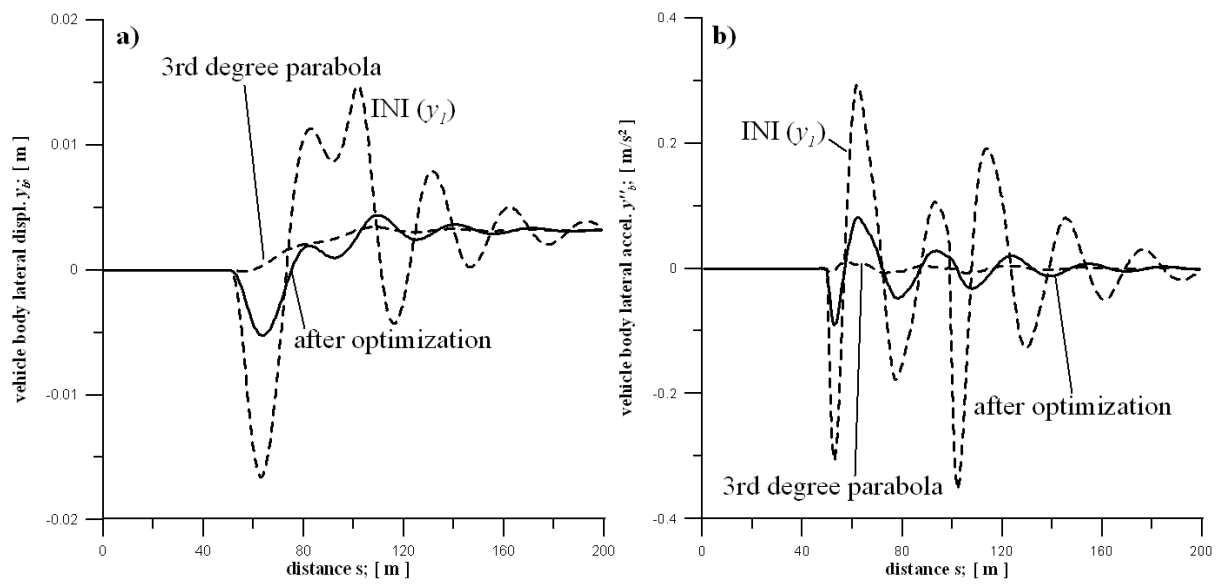

Fig. 3. Route 1: results of simulation for vehicle body for the initial, optimised and $3^{\text {rd }}$ degree parabola TCs:

a) lateral displacement, b) lateral acceleration

The ratio of value of the quality function for the TC (5.1) to the value of quality function for the $3^{\text {rd }}$ degree parabola was $7.73=\left(0.26708\left[\mathrm{~m} / \mathrm{s}^{3}\right] / 0.034511\left[\mathrm{~m} / \mathrm{s}^{3}\right]\right)$. The $3^{\text {rd }}$ degree parabolic TC however appeared to be the TC with the best dynamical properties. It is confirmed not only by the above ratio of $Q F s$ values, but also by the dynamics of vehicle. This can be seen in Fig. 3. It can possibly be explained by the fact that $3^{\text {rd }}$ degree parabolic TC does not have the point of inflection in its middle part. In such a case, the superelevation ramp slope is lower then for the smooth TCs, and the vehicle enters, passes, and exits this zone more smoothly. 
Despite these facts, the authors in their earlier works (e.g. [6], [10]) showed cases, especially for TCs of higher degrees $9^{\text {th }}$ and $11^{\text {th }}$ (for $R=600 \mathrm{~m}$ and $H=150 \mathrm{~mm}$ ), where the best (optimum) TCs had shapes (curvatures) different from the mentioned $3^{\text {rd }}$ degree parabola; these shapes were something between the standard curves given in [12] and the $3^{\text {rd }}$ degree parabola.

Formula (5.1) can be used by engineer-practitioners as the example of TCs having good dynamical properties, significantly better than the Bloss curve. The curve (5.1) is in fact the example of general TC (3.1), where the authors assumed $R=1200 \mathrm{~m}$ and $l_{0}=48.73 \mathrm{~m}$. The engineer-practitioner should just change the corresponding values $R$ and $l_{0}$ in formula (5.1) and after that he can obtain formulas (3.2) and (3.3).

\subsection{COMMENT ON THE RESULTS FOR ROUTE 3}

As a complement to results from subchapter 5.1., here the authors present two figures that show changes in the value of the quality function $\left(Q F_{l}\right)$ depending on the number of steps (iterations) $i_{\text {lim }}$ and the distance (route length) travelled by the vehicle.

As the example, the authors took the results for Route 3 as those with one of the best improvement in vehicle dynamics. Here, the optimization procedure has found the optimum solution in the $137^{\text {th }}$ step of iteration. The value of $Q F$ for $y_{1}$ TC (Bloss curve - step no. 1) was equal to $5.0954 \mathrm{~m} / \mathrm{s}^{3}$, whereas the value of $Q F$ for the optimum TC (step no. 137) was equal to $0.026066 \mathrm{~m} / \mathrm{s}^{3}$. These two values are indicated in Fig. 4a. The ratio of first and last values was equal to 0.005 , and so the great

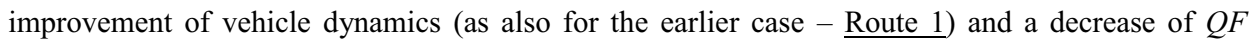
value can be observed. Peaks in Fig. 4a mean that the program found TCs which don't satisfy conditions imposed on the geometry (subchapter no. 3.2). Then, a large penalty value of $Q F$ is given for them and such cases don't have a chance to be an optimum solution. For the case in Fig. 4a such a situation took place 5 times.

In Fig. $4 \mathrm{~b}$ we see a decline in the value of quality function versus distance (route length) travelled by the vehicle in a single (last) $137^{\text {th }}$ step. In $\underline{\text { Route } 3}$ the total distance travelled by the vehicle in each step was equal to $179.24 \mathrm{~m}(\mathrm{ST}+\mathrm{TC}+\mathrm{CC}=50 \mathrm{~m}+29.24 \mathrm{~m}+100 \mathrm{~m})$. The program calculates the non-zero value of $Q F$ only at the time of entry of vehicle into transition curve (after the first $50 \mathrm{~m}$ ). For straight track this value is always equal to 0 . Due to the fact that accelerations and velocity of changes of the accelerations of vehicle body disappear in CC (see Fig. 3b), the value of the integral from formula (2.1) reaches approximately constant value in a circular arc, and then $Q F$ values from that moment have quasi-hyperbolic character versus the travelled distance. 

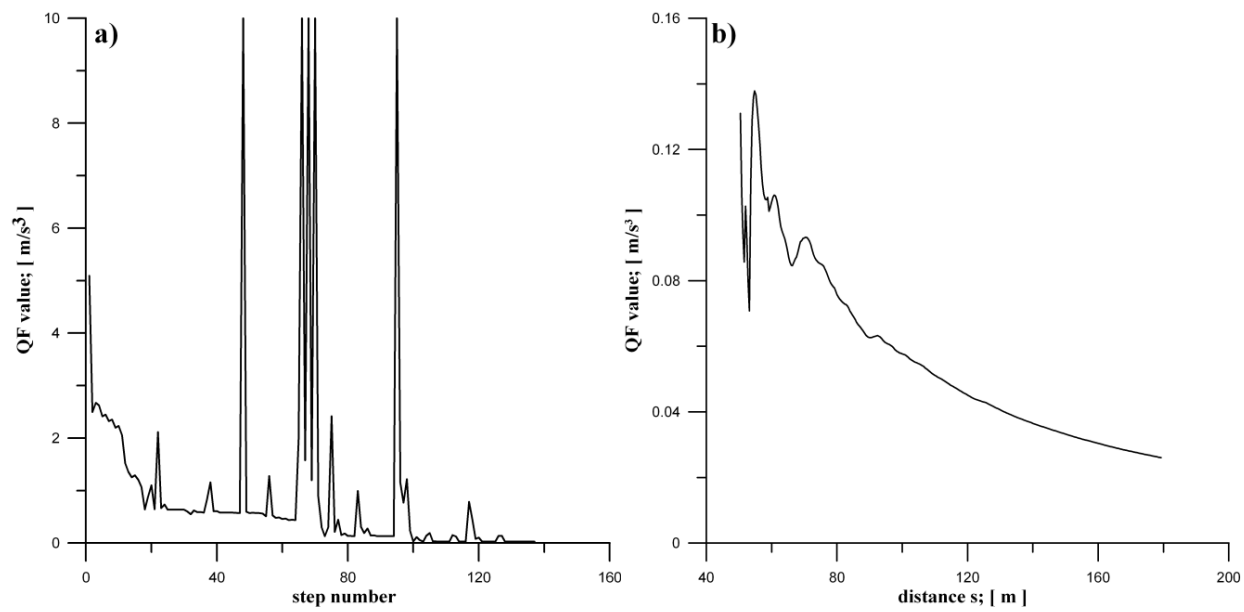

Fig. 4. Route 3 : the value of the quality function as a function of: a) the number of steps (iterations) $i_{\text {lim }}$, b) the distance (route length) travelled by the vehicle

\subsection{COMMENT ON THE RESULTS FOR TCS OF $7^{\mathrm{TH}}$ AND $9^{\mathrm{TH}}$ DEGREE}

As mentioned in subchapter 5.1, the results of the optimization of transition curve for Route 1: optimum shapes of railway transition curves and lateral displacements $y_{b}$ and accelerations $y^{\prime \prime} b$ of vehicle body corresponding to them, presented here as representative results for all the Routes and all the degrees of polynomials examined, had very similar courses. The curvatures of all optimum transition curves had a slightly convex character, such as the shape of the curvature from Fig. 2a, or even the linear shape for $3^{\text {rd }}$ degree parabolic transition curve, e.g. as for the $9^{\text {th }}$ degree, Route 11 and $Q F_{2}$.

Obtaining such results can be explained by the fact that the lengths of transition curves - calculated according to formulas (4.4) and (4.5) - in majority of the cases analyzed were no bigger than $70 \mathrm{~m}$. For smooth transition curves and such lengths of the curve - taking into account of existence of the inflection point in the midpoint of the curve - the dynamics of the vehicle in mentioned part of the curve are not smooth. Transition curves with the linear shape of the curvature for $3^{\text {rd }}$ degree parabolic transition curve do not have such a property, and the dynamics of the vehicle in the mentioned part of the curve are more smooth. The curvatures' bends in the terminal points of the obtained transition curves have a relatively small negative impact on vehicle dynamics while running along such curves. 


\section{CONCLUSiOnS}

As a result of the discussed studies, many original and important conclusions can be drawn. In the background of the authors' achievements within current article sits a model of construction, tests, and demonstrations of the high reliability of the complex software used in order to optimise the shape of the spatial (3-dimensional) transition curve. Though this task can be regarded as nontrivial, not only because of the complexity of the calculations, but also because of preparing a postprocessor to enable recording, archiving, and interpretation of very large numbers of results of different nature.

The authors of this paper can also formulate the detailed conclusions based directly on the calculation results.

First, in the optimization processes, the authors set TCs of $5^{\text {th }}, 7^{\text {th }}$, and $9^{\text {th }}$ degrees with curvatures which did not posses a tangency at terminal points. New values of curve radius $R=1200 \mathrm{~m}$ and $2000 \mathrm{~m}$ - and cant $-H=75 \mathrm{~mm}$ and $45 \mathrm{~mm}$ - and new assessment criteria concerning jerk taken into analysis did not give so-called smooth transition curves as a result.

Secondly, as mentioned, the curvatures' bends at terminal points of obtained transition curves had a relatively small negative impact on vehicle dynamics while running along such curves. This is just the bend in the course of the trajectory characteristic quantity - curvature, and not in the trajectory itself. This quantity has of course an important physical interpretation and can affect the dynamic behaviour, but it seems to be smaller than in the case of bends directly in the trajectory (track). Thus, bends in superelevation ramp should have rather greater importance.

Third, the software used by the authors allows for many possibilities of optimization of TCs and through it the authors hope to perform the optimization of e.g. inverse TCs. The results of preliminary optimization of inverse TCs were presented in [2] and [6]. 


\section{REFERENCES}

1. J. Sysak, „Drogi Kolejowe”, PWN, Warsaw, 1982.

2. P. Woznica, „Kształtowanie i ocena własności kolejowych krzywych przejściowych z wykorzystaniem metod optymalizacji i symulacji”, Ph.D. Thesis, Warsaw University of Technology, Warsaw, 2012.

3. Rozporządzenie MTiGM w sprawie warunków technicznych, jakim powinny odpowiadać budowle kolejowe i ich usytuowanie - Dz.U. nr 151 poz. 987, 1998 r. z póżn. zm. - Dz.U. poz. 867, 2014 r.

4. W. Koc, „Krzywe przejściowe z nieliniowymi rampami przechyłkowymi w warunkach eksploatacyjnych PKP”, Zeszyty Naukowe Politechniki Gdańskiej - Budownictwo Lądowe, no. 47, 1990.

5. W. Koc, R. Radomski, „Analiza krzywych przejściowych z nieliniowymi rampami przechyłkowymi”, Drogi Kolejowe, 11, pp. 261-267, 1985.

6. K. Zboinski, „Nieliniowa dynamika pojazdów szynowych w łuku” (book in Polish), WNITE, Warsaw-Radom, 2012.

7. K. Zboinski, „Numerical studies on railway vehicle response to transition curves with regard to their different shape", Archives of Civil Engineering, 44(2), pp. 151-181, 1998.

8. K. Zboinski, P. Woznica, „Optimisation of Railway Polynomial Transition Curves: A Method and Results”, in J. Pombo, (Editor), Proceedings of the First International Conference on Railway Technology: Research, Development and Maintenance, Civil-Comp Press, Stirlingshire, UK, Paper 60, 2012, doi:10.4203/ccp.98.60.

9. K. Zboinski, P. Woznica, „Optimisation of the railway transition curves' shape with use of vehicle-track dynamical model”, Archives of Transport, 22(3), pp. 387-407, 2010.

10. K. Zboinski, P. Woznica, „Optimisation of railway polynomial transition curves with different number of terms”, Logistics\&Transport, vol. 2, no. 2, 2014.

11. K. Zboinski, „Dynamical investigation of railway vehicles on a curved track”, European Journal of Mechanics A-Solids, vol. 17, no. 6, 1998.

12. X.Y. Long., Q.C. Wei, F.Y. Zheng, „Dynamical analysis of railway transition curves”, Proc. IMechE part F Journal of Rail and Rapid Transit, 224(1), pp. 1-14, 2010 


\section{LIST OF FIGURES AND TABLES:}

Fig. 1. System's nominal model: a) track vertically, b) track laterally, c) vehicle

Rys. 1. Model nominalny układu: a) model pionowy tory, b) model poziomy toru, c) pojazd

Fig. 2. Route 1: features of TCs: a) curvatures, b) superelevation ramp slope of the initial and optimum TCs

Rys. 2. Trasa 1: cechy krzywych przejściowych: a) krzywizny, b) pochylenia rampy przechyłkowej krzywej początkowej i optymalnej

Fig. 3. Route 1: results of simulation for vehicle body for the initial, optimised and $3^{\text {rd }}$ degree parabola TCs: a) lateral displacement, b) lateral acceleration

Rys. 3. Trasa 1: wyniki symulacji środka masy nadwozia pojazdu dla krzywej początkowej, optymalnej i paraboli 3. stopnia: a) przemieszczenia poprzeczne, b) przyspieszenia poprzeczne

Fig. 4. Route 3: the value of the quality function as a function of: a) the number of steps (iterations) $i_{\text {lim }}$, b) the distance (route length) travelled by the vehicle

Rys. 4. Trasa 3: wartości funkcji celu w funkcji: a) liczby kroków (iteracji) $i_{\text {lim }}$, b) drogi przebytej przez pojazd

Tab. 1. Parameters of the analysed vehicle-track system

Tab. 1. Parametry analizowanego układu pojazd-tor

Tab. 2. Conditions taken to the analysis - different Routes

Tab. 2. Warunki przyjęte do analizy - różne Trasy 


\section{OPTYMALIZACJA WIELOMIANOWYCH KRZYWYCH PRZEJŚCIOWYCH Z PUNKTU WIDZENIA WIELKOŚCI ZRYWU}

Slowa kluczowe: kolejowe wielomianowe krzywe przejściowe, symulacja komputerowa, optymalizacja

\section{STRESZCZENIE:}

Celem pracy była optymalizacja kolejowych wielomianowych krzywych przejściowych 5., 7. i 9. stopnia z wykorzystaniem nietradycyjnych kryteriów oceny i pełnego dynamicznego modelu pojazdu. W niniejszej pracy autorzy chcieli także sprawdzić, czy nowe kryteria oceny i nowe wartości promienia łuku - $R=1200 \mathrm{~m}$ do $2000 \mathrm{~m}$ i przechyłki - $H=75 \mathrm{~mm}$ i $45 \mathrm{~mm}$ - przyjęte w pracy dadzą w wyniku krzywe przejściowe gładkie.

Jako wspomniane nietradycyjne kryteria oceny autorzy zastosowali tu minimalizację:

- wartości całki ze zmiany przyspieszenia poprzecznego (zrywu) nadwozia pojazdu po długości drogi,

- maksymalnej wartości zmiany przyspieszenia poprzecznego (zrywu) nadwozia pojazdu.

W pracy tej użyto jeden model pojazdu kolejowego. Model przedstawia 2-osiowy wagon towarowy o uśrednionych wartościach parametrów. Mimo wirtualnego charakteru ma on cechy typowego 2-osiowego wagonu rzeczywistego. Jest rozważany w stanie ładownym. Stosunkowo prosta konstrukcja pojazdu daje akceptowalne czasy obliczeń, co jest korzystne w badaniach podstawowych i ułatwia interpretację wyników. Jego strukturę przedstawiono na rys. 1c. Jest on uzupełniony o dyskretny pionowo i poprzecznie model toru pokazany na rys. 1a i $1 \mathrm{~b}$. W modelu przyjęto liniowość zawieszenia pojazdu. Zastosowano więc liniową sztywność i thumienie elementów zawieszenia pojazdu. To samo dotyczyło modelu toru.

Zastosowany model zawiera wszystkie kluczowe elementy modeli dynamicznych pojazdów szynowych, takie jak: kluczowe elementy masowe (zestawy kołowe i nadwozie pojazdu), elementy zawieszenia (elementy sprężyste i thumiące), koła i geometrię szyn opisaną przez rzeczywisty, nieliniowy kształt ich profili. Poza tym, styczne siły kontaktowe są obliczane przy użyciu uproszczonej nieliniowej teorii kontaktu J.J. Kalkera. Oprócz tego, wszystkie składowe bezwładności wynikające z ruchu w łuku kołowym są brane pod uwagę bez uproszczenia. Ponadto, model pojazdu jest uzupełniony modelem toru, co oznacza, że w rzeczywistości rozważany jest układ dynamiczny pojazd-tor. Może on być traktowany jako zaawansowany model dynamiczny, zwłaszcza gdy porówna się go do punktu materialnego reprezentującego pojazd w tradycyjnych metodach oceny i kształtowania krzywych przejściowych.

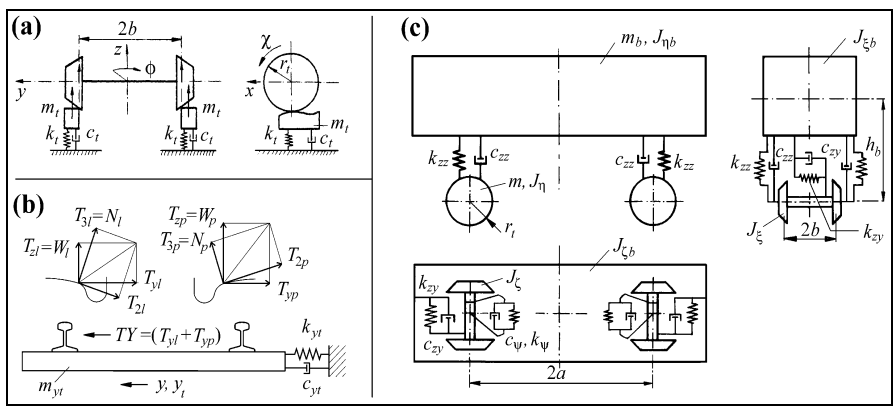

Rys. 1. Model nominalny układu: a) model pionowy tory, b) model poziomy toru, c) pojazd 
Jak już wspomniano, przyjęto promień łuku kołowego $R$ równy $1200 \mathrm{~m}$ i $2000 \mathrm{~m}$ oraz przechyłkę równą $75 \mathrm{~mm}$ i $45 \mathrm{~mm}$. Dla konkretnych wartości $R$ i $H$, autorzy zawsze obliczali dwie prędkości pojazdu: mniejszą i większą, zgodnie ze wzorami tradycyjnie przyjętymi w praktyce inżynierskiej. Mniejsza prędkość zawsze odpowiadała przyspieszeniu poprzecznemu $a_{\text {lim }}$ w płaszczyźnie toru równemu $0 \mathrm{~m} / \mathrm{s}^{2}$, natomiast większa prędkość odpowiadała przyspieszeniu poprzecznemu $a_{\text {lim }} \mathrm{w}$ płaszczyźnie toru równemu $0,3 \mathrm{~m} / \mathrm{s}^{2}$ lub $0,6 \mathrm{~m} / \mathrm{s}^{2}$. Pełny wykaz warunków symulacji przyjętych do analizy przedstawiono w poniższej tabeli.

Warunki przyjęte do analizy - różne Trasy

\begin{tabular}{|c|c|c|c|c|c|}
\hline $\begin{array}{c}\text { Promień łuku } \\
R[\mathrm{~m}]\end{array}$ & $\begin{array}{c}\text { Przechyłka } \\
H[\mathrm{~mm}]\end{array}$ & $\begin{array}{c}\text { Przyspieszenie } \\
\text { poprzeczne } \\
a_{\text {lim }}\left[\mathrm{m} / \mathrm{s}^{2}\right]\end{array}$ & $\begin{array}{c}\text { Prędkość pojazdu } \\
v[\mathrm{~km} / \mathrm{h}]- \\
5 . \text { stopień }\end{array}$ & $\begin{array}{c}\text { Prędkość pojazdu } \\
v[\mathrm{~km} / \mathrm{h}]- \\
\text { 7. stopień }\end{array}$ & $\begin{array}{c}\text { Prędkość pojazdu } \\
v[\mathrm{~km} / \mathrm{h}]- \\
9 . \text { stopień }\end{array}$ \\
\hline \multirow{2}{*}{1200} & \multirow{2}{*}{75} & 0,0 & 87,33 (Trasa 1) & $87,33(\underline{\text { Trasa } 5)}$ & 87,33 (Trasa 9) \\
\hline & & 0,6 & 130,21 (Trasa 2) & $130,21($ Trasa 6$)$ & $130,21($ Trasa 10$)$ \\
\hline \multirow{2}{*}{2000} & \multirow{2}{*}{45} & 0,0 & 87,33 (Trasa 3) & 87,33 (Trasa 7) & 87,33 (Trasa 11) \\
\hline & & 0,3 & $130,21$ (Trasa 4$)$ & $130,21(\underline{\text { Trasa } 8)}$ & 130,21 (Trasa 12) \\
\hline
\end{tabular}

W niniejszej pracy autorzy zaprezentowali wybrane wyniki optymalizacji kształtu krzywych przejściowych dla

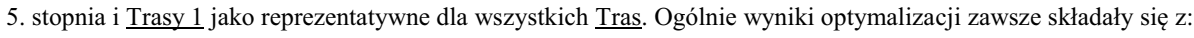

- wzoru na optymalną KP,

- $\quad$ wzoru na krzywiznę odpowiadającą KP optymalnej,

- wartości optymalnych współczynników wielomianu,

- wartości funkcji celu odpowiadającej optymalnym współczynnikom wielomianu,

- graficznej reprezentacji poślizgów w kontakcie koło-szyna,

- graficznej reprezentacji przemieszczeń $y_{b}$ i przyspieszeń $y^{\prime \prime}{ }_{b}$ poprzecznych pojazdu i zestawów kołowych,

- graficznej reprezentacji obrazu poszukiwania optymalnej KP reprezentowanej przez krzywizny (rampy przechyłkowe). 